\section{Géneros}

Multidisciplinary Journal of Gender: Studies

\section{Hipatia Press \\ www.hipatiapress.com}

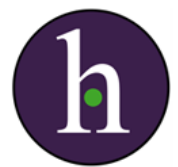

Instructions for authors, subscriptions and further details:

$\underline{\text { http://generos.hipatiapress.com }}$

\title{
Gender and School Leadership: Breaking the Glass Ceiling in South Africa
}

Clever Ndebele ${ }^{1}$

1) Sefako Makgatho Health Sciences

University, South Africa

Date of publication: June $25^{\text {th }}, 2018$

Edition period: June - October 2018

To cite this article: Ndebele, C. (2018). Gender and School Leadership:

Breaking the Glass Ceiling in South Africa. Multidisciplinary Journal of Gender Studies, 7(2), 1582-1605. doi: 10.17583/generos.2018.3179

To link this article: http://dx.doi.org/10.17583/generos.2018.3179

\section{PLEASE SCROLL DOWN FOR ARTICLE}

The terms and conditions of use are related to the Open Journal System and

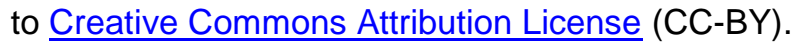




\section{Gender and School Leadership: Breaking the Glass Ceiling in South Africa}

Clever Ndebele

Sefako Makgatho Health Sciences University

\section{Abstract}

This study looked at leadership from a gender perspective in a rural context in South Africa. The study investigated the challenges faced by female school principals because of their gender in one rural district. Grounded in the qualitative paradigm and using the social realist theoretical analytical framework, a thematic approach was used in analysing qualitative data gathered through semi-structured interviews with ten female school principals. Findings showed that female school principals were not perceived as incompetent and unable by male colleagues only, but also by female staff colleagues as a result of an entrenched culture of male dominance. Among the challenges faced by female principals included: negative attitude from some parents and educators; being undermined because of their gender and lack of confidence on their side. The study recommends the mounting of gender awareness workshops with both parents and educators to sensitive them on gender equity issues. In addition the study calls for mentoring and networking workshops, in service training opportunities and role modelling to be given to female teachers who aspire to, and have potential in leadership so that these female teachers can feel empowered and see that they have the potential of being leaders.

Keywords: empowerment, gender, principals, leadership, glass ceiling 


\title{
Género y Liderazgo Escolar: Romper el Techo de Cristal en Sudáfrica
}

\author{
Clever Ndebele \\ Sefako Makgatho Health Sciences University
}

\section{Resumen}

Este estudio examinó el liderazgo desde una perspectiva de género en un contexto rural en Sudáfrica. El estudio investigó los retos a los que se enfrentan las mujeres directores de escuelas debido a su género en un distrito rural. Fundada en el paradigma cualitativo y utilizando el marco analítico teórico realista social, se utilizó un enfoque temático para analizar los datos cualitativos obtenidos a través de entrevistas semiestructuradas con diez directores de escuela femeninos. Los hallazgos mostraron que los directores de las escuelas femeninas no eran percibidos como incompetentes e incapaces sólo por colegas masculinos, sino también por colegas del personal femenino como resultado de una cultura arraigada de dominación masculina. Entre los retos a los que se enfrentan las directoras de sexo femenino se encuentran: la actitud negativa de algunos padres y educadores; Siendo socavados por su género y falta de confianza de su parte. El estudio recomienda la realización de talleres de sensibilización sobre el género con padres y educadores para sensibilizarlos sobre cuestiones de equidad de género. Además, el estudio requiere talleres de tutoría y trabajo en red, oportunidades de capacitación en servicios y modelización de roles para las maestras que aspiran y tienen potencial de liderazgo para que estas maestras puedan sentirse empoderadas y ver que tienen el potencial de ser Líderes.

Palabras clave: empoderamiento, género, principios, liderazgo, techo de cristal 
ender inequality in leadership has been the central focus of studies in the field of educational administration for many years (NanChi, 2006; Kiamba, 2008; Bilen-Green, 2008; Nazemi et al. 2012; Zinyemba, 2013; Shava \& Ndebele 2014; Morley \& Crossouard, 2016a). Throughout history, leadership roles were generally held by men (Sloan, 1999; Merchant, 2012; Day, 2014; Longman \& Anderson, 2016). This social attitude or 'injustice' seems to have made women reluctant to pursue administrative leadership positions (Anewu, 2010). Msila (2013) posits that women leaders do not always get the necessary support from the communities and usually have to prove their capability as leaders under trying conditions in the patriarchal society. There is much literature which shows that mistrust in women leadership is caused by a number of factors and these include tradition and culture (Cundiff \& Vescio, 2016; Msila, 2013; Morley \& Crossouard, 2016a). Lumby (2003) also contends that communities do not trust women to be appointed as school managers because school management is an important job which demands the seriousness they think only men could provide. The aim of this study was to investigate challenges faced by female school principals in their day to day running of schools in one rural district in South Africa.

\section{Gender and school leadership}

There has been a lot of research on gender and school leadership the world over, (Hoobler, Lemmon \& Wayne, 2011; Schwanke, 2013; Chaluvadi, 2015; Madsen, Ngunjiri, Longman, \& Cherrey, 2015; Burton \& Weiner, 2016). The literature generally shows that females are underrepresented in management positions in both the schooling system (Burton \& Weiner 2016; Gobena, 2014; Lunyolo, Ayodo, Tikoko \& Simatwa, 2014; Uwizeyimana, Modiba \& Mathevula, 2014) and in higher education (Austin, 2016; Drake, 2015; Hannum, Muhly, Zalabak \& White, 2015; Howe-Walsh \& Turnbull, 2016; Shava \& Ndebele, 2014). Females are often expected to stay at home instead of taking up roles previously dominated by males, such as school management. At each step of administrative preparation, job seeking and selection, there are organizational processes that clearly indicate a preference for males (Hill, Miller, Benson \& Handley, 2016; Hora, 2014; Lunyolo, Ayodo, Tikoko \& Simatwa, 2014). Stereotypical assumptions about the 
gender differences between men and women make conditions difficult for women to obtain the opportunity to be placed in senior leadership positions (Davis \& Maldonado, 2015; Morley \& Crossouard, 2016b). According to Drake and Owen (1998), in Indonesia, women executives experienced obstacles in the environment and stereotyping about gender roles which typecast them into nurturing, supporting types of jobs. There seems to be a patriarchal male culture of dominance and many schools tend to be saturated with masculine values (Bush \& West-Burnahm, 1994: Davis and Maldonado, 2015). The domination of males leads to discrimination against females (Shakeshaft, 1993). Some males assume that certain gender roles are natural and normal (Hill, Miller, Benson \& Handley 2016), while females are subjected to a patriarchal culture, where most of the responsibilities belong to males (Bush \& West-Bumharn, 1994; Cundiff \& Vescio, 2016; Gill \& Arnold, 2015). As Hill, Miller, Benson \& Handley (2016) show, whereas men are socialized to be confident, assertive, and self-promoting, cultural attitudes toward women as leaders continue to suggest to women that it is often inappropriate or undesirable to possess those characteristics.

\section{Supporting Gender Equity in South Africa}

In South Africa, the large number of females in the education profession shows a history of domination and exploitation based on essentialist notions of womanhood rather than of encouraging the clear development of women (Department of Education, 1997). The existence of males as "gatekeepers" has been identified as a crucial organizational factor limiting the entrance of females to educational management (Shava \& Ndebele, 2014).

Mdluli (2002) strengthens this argument by indicating that only $9.3 \%$ of managerial positions are held by women in South Africa. This percentage of merely $9.3 \%$ can be attributed to many factors, including amongst other things the misperceptions about women leadership skills and potentials. Such a low percentage of women in managerial positions reflects discrimination at the workplace if one considers that women constitute $55 \%$ of the South African population (Mdluli, 2002). With regards to the education sector, as Kele \& Pietersen (2015) show, history has shown that, females, regardless of their race, have been underrepresented in leadership positions in South African higher education institutions for quite some time, while in the schooling sector, according to Wills (2016: 28), "despite the 
feminisation of the teaching profession, school leadership positions are dominated by men," Wills (2016) notes that in 2012, 71 percent of all teachers were women but they held a mere 36 percent of school principal positions.

South Africa has emerged from a socio-political order that was characterized by discrimination against, and neglect of females. The new South African constitution has gone a long way towards ending this state of affairs. For example, according to Section 9 of the Constitution of the Republic of South Africa (Act No. 108 of 1996), all South Africans are equal before the law. This equality imperative is not readily observable in the management positions at school level (Zwane, 2003). In this regard, Moorosi (2008) also concurs when she contends that in the schooling system women form only $30 \%$ of school principals although they constitute the majority (more than $70 \%$ ) of the teaching population.

Gender inequity is still very much part of the South African education system. Greyvenstein (2000: 75) asserts that "the traditional inequity between men and women may be traced throughout history, where it has been cloaked in the androcentric (male-centered) philosophies." As the South African education system is undergoing a transformation process, both men's and women's abilities need to be used in managerial positions in order for the transformation to take place effectively. Yet women's under representation in managerial positions is not always acknowledged and given the necessary attention in organizations. In 1996, a Gender Equity Task Team (GETT) was established to, amongst others, identify means to correct gender imbalances, propose affirmative action strategies for increasing the representation of women in professional leadership and management positions and for increasing the influence and authority of women leaders. (Chisholm \& September, 2005). Although the GETT report (1997) made the recommendations to ensure that equality in education takes place, unequal distribution of men and women in leadership positions in education is still a reality in South Africa (Chisholm \&September, 2005).

While there is a gradual change today, women leaders are still far from achieving equality in the workplace in South Africa (Msila, 2013). Whilst many will argue that the status of women in the workplace is gradually changing, it is doing so at a sluggish pace: sometimes even women have internalized that they are not ready for leadership and management jobs 
(Msila, 2013). After reviewing literature related to South Africa, Greyling \& Steyn (2015) conclude that research shows an underrepresentation of women in management positions at all levels of the education system, including primary schools, high school, universities and other educational institutions.

The paucity of women in management, therefore, suggests acute gender misrepresentation in leadership. It is important to research experiences of female leaders as these experiences might be detrimental to their performance. As Mollel \& Tshabangu, (2014) show, female leadership is perceived less favourably and therefore an investigation of the challenges they encounter in their day to running of schools might shed light why this is the case. This study sought to investigate the challenges faced by these female principals of secondary schools in one rural district in South Africa in order to advance recommendations to mitigate the challenges. The research question of this study was: What challenges do female school managers face in their day to day running of their schools?

\section{Social realist analytical approach}

The research is premised on Archer's (1995, 1996, 2000) social realist analytical framework. Archer (2000) distinguishes between the people (agents) and the parts (structure and culture). She provides a model of social reality as comprising three milieus: structure, culture and agency. Archer's social realism is an explanatory framework for examining and explaining the social world through analysis of the interplay between structure, culture and agency $(1995,2000)$. Archer challenges existing social theories that conflate the analysis of the social world. Archer advocates for the theory of 'analytical dualism' where she argues that the 'parts' (culture, structure) and the 'people' (agents) are two irreducible parts in a social world therefore they need to be analysed separately to avoid what she calls the 'fallacy of conflation'.

The structural domain in Archer's social realist theory comprises things which exist in the system, such as policies (for example, which spell out the government position with regards to gender equity and the appointment of females in leadership positions) and committees (which are for example, responsible for the appointment of school principals). These structures, either constrain or enable the actions of the agents (for example, the beliefs 
of selection committee members would have an impact on whether females are appointed into principals positions), and in turn, agents reproduce and/or transform structures (Danermark et al. 2005).

Culture, according to Archer's theory, comprises our value systems, beliefs, attitudes, ideas, ideologies, theories and concepts which are manifest through discourses that are used by particular people at particular times (Quinn, 2012). The beliefs held by teachers and communities, for example, on the qualities of a good leader or on whether there are gender differences with regards to leadership ( for example, whether or not females can lead as effectively as males) have an important influence on how female school principals are accepted and/or viewed in schools.

Agency (the people), according to Archer (1996), refers to the personal and psychological makeup of individuals, their social roles and relates to the capacity that people have to act in specific ways. Agents can engage in concerted action to re-shape or retain the structural or cultural features they inherit in specific institutional settings. Agents coming onto the scene (such as new female principals being appointed) inherit a set of doctrines, theories and beliefs which dictate what could have an impact on them and these shape what these agents (female principals) can do (Quinn, 2006). Agents, for example, new female school principals coming into a system where the generally held belief is that school leadership is for males can have a causal effect on the beliefs held about gender disparity in leadership by modelling good leadership and producing good results or perpetuate the belief that females are not good enough (by adopting male masculinity attributes in their leadership). Archer thus believes that social structures exert causal influence on social interactions, while the actions of individuals and groups affect social structures by modifying or reproducing them.

This analytical theoretical framework is used this paper to analyse the challenges faced by female school principals in their day to day running of schools. As Archer's social realist theory shows, structure and culture can influence the extent to which female school principals are accepted as leaders. This paper unpacks, from the data collected, the extent to which existing structures in the schooling system either enable or constrain the female school principals in their day to day running of schools. In order to infer from Archer's domain of culture, the paper discusses the extent to which societal patriarchal beliefs about the ability of women to lead affects 
the female principals' roles. In the domain of agency, the paper considers the extent to which the female school principals (as agents) are able to mitigate these challenges and break the 'glass ceiling'.

\section{Methodology}

This study was grounded in the qualitative paradigm. Denzin \& Lincoln (2000: 370) point out that "qualitative researchers seek out individuals, groups and settings where the specific processes being studied are most likely to occur." The researcher chose a qualitative research approach to provide an in-depth investigation of challenges faced by women principals of secondary schools in one district in South Africa. Purposeful sampling was used to select participants for the study. In purposive sampling, researchers handpick the cases to be included in the sample on the basis of their judgement of their typicality (Kaparou \& Bush, 2007). As the concern was on female principals, only female principals were purposefully targeted. After identification of all female principals in the district, a random sample of ten female principals was then selected for interview. Data were collected by means of semi-structured interviews. According to Wragg (1994), the semi-structured interview schedule tends to be the one most favoured by educational researchers as it allows respondents to express themselves at some length, but offers enough shape to prevent aimless rambling. The interviews were conducted at the schools, which was the natural work setting for the principals. The interviews were recorded and transcribed verbatim (Mayer \& Surtee, 2015). Content analysis was used to identify emerging themes from the data.

\section{Results}

The results are presented below using Archer's (1995, 1996, 2000) social realist analytical framework under the following subheadings; receipt of female principals at schools, attitudes of teachers towards female principals, attitudes of School Management Team (SMTs) towards female principals, and attitudes of the parents and the School Governing Board (SGB) members towards female principals, work-related challenges faced by Female Principals and personal challenges faced by female principals. 


\section{Receipt of Female Principals by educators and SMT members at schools}

There was a question which sought to find out how female principals were received by both male and female educators and SMT members at schools. Female Principals indicated that their receipt by other staff members at the schools was not good. Seven out of the ten Female Principals indicated that their receipt by School Management Teams was negative and an element of doubt and lack of trust was evident from among SMT members. They indicated that fellow staff at the schools were not pleased, partially welcomed them and there was an element of doubt. In this regard, principals P6, P7 and P9 said:

P 6: It was not easy for educators to accept me as their leader. Most male educators when not pleased because of their cultural belief that a man is a head everywhere.

P 7: At first teachers were not friendly. They hardly received me as a new female principal. They were reluctant to receive me as their leader.

P9: Negative tradition and culture loyalists do not take women as individuals who could take decision and lead the majority.

Opposing camps were said to emerge in the schools with some members of the School Management Team siding with the former acting principal if one was still at the school. From the responses it is clear that male dominance was an entrenched culture among the SMT members as illustrated in the following responses:

P4: The SMT members who were siding with the former male acting principal opted out from their positions as they were also on acting capacity.

P9: Negatively there is male dominance. They don't have confidence in women. They undermine you and try to challenge you.

From the responses it is apparent that traditional stereotypes were the major cause of rejection of female principals in schools which falls under 


\section{Ndebele - Gender and School Leadership}

Archer (2000) domain of culture. From the responses it is also clear that male dominance was an entrenched culture among the SMT members. As Archer (2000) shows, structures, in this case the SMT as a structure, can either constrain or enable the actions of the agents (for example, the beliefs of SMTs on the ability of females to lead had an impact on how the female principals were received and supported.) In can be concluded that traditional stereotypes in the SMT structure were the major cause of rejection of female principals in these schools. As Chan et al. (2016) argue, when gender norms in society prescribe different, and often inferior, roles to women, these shape the way schools are organised and the social perception of leadership. "Sexism tends to prevail when the school management or selection committee is dominated by men, who are more likely to hire and promote other men who look, think and act like them." (Chan et al. 2016: 195) These findings of this study also concur with those by Faulkner (2015) who notes that despite the equal opportunities legislation introduced in many countries, including South Africa, in the last three decades, traditional stereotypes of women's roles, position, characteristics and abilities continue to exist. For female principals to break this glass ceiling, they need to invoke and exercise their agency. As Chan et al. (2016) notes, almost total absence of formal institutional support implies that women have to turn to their own means (agency) and bear personal costs when pursuing career progression.

Notwithstanding the concerns above, however, there were some principals who indicated that they had been positively received. Of the ten Principals interviewed three indicated that the attitude of SMTs was positive. In this regard P2 for example said SMTs were very much cooperative.

\section{Attitudes of the parents and the SGB members}

The general attitude of SGB members towards female principals was positive even though there were elements of doubt in beginning. Female principals indicated that parents and SGB members were supportive and had developed trust in them. There were however a few SGBs that were seen to be negative. According to Archer's (2000) framework, structures play a significant role determining whether these female principals are accepted. In this case the SGB as a structure is seen as supportive. This is evidenced in the following responses from principals P3, P5, P7, and P9: 
P 5: Parents and SGB were very happy to have me as their principal. Even the enrolment is increasing because they have trust in me.

P8: Some parents and SGB were very much supportive whilst others were in doubt, but my performance after the first semester won me their trust.

P9: They do not trust or have confidence in women. They gain confidence gradually as you will find them engaging themselves actively in school matters.

P3: They were negative before after seeing development they started to have confidence.

The results show that the general attitude of the community towards female principals were positive even though there was an element of doubt in the beginning with female school principals indicating that parents and SGB members were supportive and had gradually developed trust in them. The South African Schools Act 84/1996 states that all stakeholders in education must accept responsibility for the organization of schools. Section B of the SASA 84/1996 points out that parents and members of local communities are often in the best position to know what a school really needs and what the problems are. Section B of The South African School Act (SASA) allows for all stakeholders including parents, educators, students and the school community to participate as the school governing body (SGB). According to Van Deventer \& Kruger (2003:262) the South African government states that education can only succeed if all stakeholders are involved in the running of the school by being actively involved and accepting their responsibilities. The results of this study seem to contradict those of Faulkner (2015) who found that the women's experiences of principalship were adversely affected by the prevailing and entrenched patriarchal attitudes within the communities they served and those of Zikhali \& Perumal (2016) in which the female school heads commented that the community looked down upon them as they thought that women were not good leaders. 


\section{Work-related challenges faced by Female Principals}

Findings of the study showed that female principals faced a number of challenges as they assumed their roles for the first time. Amongst the challenges faced included: negative attitude from some parents and educators; jealousy; being undermined because of their gender and lack of confidence on their side (Principal's side). P3, P7 and P9 for example said:

P3: Parents are not immediately cooperative. They gradually gain confidence and then suddenly have trust and confidence towards you.

P7: At first I was a bit nervous to get this post. My main problem was to be a school manager of a high enrolment school. It was scary. The infrastructure of the school was limited and old.

P9: I have been undermined by over aged learners. Most parents do not have confidence in the work I do. Male SMT members like challenging my authority.

When further asked if the challenges the principals faced were due to the fact that they were female, the general response was the principals were being undermined as females as shown in response by P3, P6 and P8:

P3: Yes, as a woman, traditionally women are not expected to take decisions.

P6: Yes, because most of the educators who shows their attitudes are male educators

P8: Yes, they were jealousy of my position as a woman.

When asked about their encounters with male teachers, female Principals indicated that some male teachers were not cooperative; did not want to take instructions and were undermining them. For example, P5 and P8 had this to say:

P 5: Male teachers are not cooperative. Some when you gave them work they just do it in their own pace. Some are too fast to take the decision they don't listen to the problem they just act before thinking. 
P 8: Some want to challenge you, but after a while they cooperative as they want to see or improve your performance.

One principal however felt the male teachers were not a problem at all and were very cooperative as shown in this response from P3: some are very respectful and willing to help while others are always ready for confrontation and always fault - finding. With regard to the general behaviour of teachers (both males and females) towards female Principals, the Principals indicated that the general behaviour was negative as there was an element of undermining and disrespect towards them. In this regard P3 and P10 said:

P 3: Undermining and sometimes disrespectful.

P10: Yes, there was one who enjoyed calling me by first name in public and I stood my ground told him in no uncertain terms that it was not professional.

Findings of the study showed that female principals were not only perceived as incompetent and unable by male colleagues only, but also by female staff members. One would expect the female colleagues to support women managers because they share the same common feature which is their femaleness, but it is not like that. Findings of the study are supported by Weeks (2009)'s research which demonstrated that women managers continue to face the perceptions of others which recognized men as more suited for management positions than women. Similarly, results from a study by Arar \& Abramovitz (2013) indicate that, on the whole, the population of Arab teachers in Israel still has prejudiced perceptions of women school principals. Even though educators are professionally trained, they continue to view women managers negatively. As the review of literature has shown, culture and tradition could have a noticeable impact on how educators view women managers. The school is an extended organ of the community. Cultural beliefs also manifest themselves in the school situation. Educators are part of society and they carry with them their cultural beliefs at their places of employment. When educators enter schools, they do not leave behind their cultural belief systems at home. Some cultural beliefs believe 
that women are inferior to men and thus cannot be managers over men. Because of their femaleness, they are thus considered to be weak and not fit for management positions. They do not believe that women managers are capable of delivering. In a Zimbabwean study, by Zikhali \& Perumal (2016), school principals made it clear that some male teachers did not want to be led by a 'petticoat' government. Furthermore, female colleagues were described as being jealous of other females. The Department of Education (Republic of South Africa 2004) cited in Nzeli (2013) observed that men and women who hold values that consider women to be inferior to men are more likely to create difficulties for women managers. Literature suggests that gender inequity is still very much part of the South African education system. Greyvenstein (2000:75) asserts that "the traditional inequity between men and women may be traced throughout history, where it has been cloaked in the androcentric (male-centered) philosophies." The underrepresentation of South African women in educational leadership and management in the literature is blamed on institutional culture, with a strong argument that unhelpful cultural expectations about women prevail to the present day (Chisholm, 2001; Diko, 2007; Diko 2014; Mahlase, 1997; Moorosi, 2008).

\section{Personal challenges faced by female principals}

A majority of the female principals indicated that they were not facing any personal challenges but the few who indicated that they had personal challenges had to do with balancing their work and their roles as mothers at home with some principals indicating that conflict had resulted with spouses and relations had been strained. In this regard P7, P8 and P10 said:

P7: Yes, as a mother there are my kids. I have to attend to them. The relationship between me and my husband is sometimes bitter and it is a challenge. I had to fix it.

P8: Balances of home - life and work, life, you spend most of your time working to your job and neglecting your family. Time is spent doing your job work and you miss to socialize. 
P10: As a family they miss to be with me at home. Time to balance my job and household chores is difficult.

This challenge of balancing their work and their roles as mothers can be classified under Archer (2000)'s domain of culture where women are expected to care for the family. This can be seen as a constraint in the domain of culture according to Archer (2000). Culture, according to Archer's theory, comprises our value systems, beliefs, attitudes, ideas, ideologies, theories and concepts which are manifest through discourses that are used by particular people at particular times. The cultural belief that it is the woman's responsibility to look after the children militates against their assuming leadership positions. As Kaparou \& Bush (2007) found in their study, women do not feel able to hold senior positions in education because of the dual demands of management and family responsibilities. The evidence from the interviews in their study revealed that motherhood took priority over work and hampered women in balancing their work and family life. Similarly, participants in a study by Longman \& Anderson (2016) opted not to pursue promotions that would require more time away from their families, favouring personal balance over higher salaries or positional authority. In this regard, Lumby \& Azaola (2014:31) aver that, "the gendering of family roles is an example of different bandwidths and of a social location where the expectations of what it is to be a mother or a father are generally different and have implications for the individual that reach far beyond the family milieu."

The results of this study as shown above also showed souring family relationships as a result of females assuming leadership positions. This could be attributed to the patriarchal culture that sees the role of the woman as that of nurturing the family. The literature also shows the importance of family support for successful leadership careers of females. Sanderson \& Whitehead (2016) report that, of the nine women interviewees who were married in their study, six commented on the fact that having a supportive partner was critical to their ability to seek promotion. In the same vein, Kaparou \& Bush (2007) report that support and encouragement from their husbands, families and peers influenced women's attitudes to promotion. 


\section{Lack of agency}

In this study, in the domain of agency, lack of confidence on their (female principals) own ability to run schools was an issue that emerged in the results as shown in these confessions by two female principals:

P4 At first I was a bit nervous to get this post. My main problem was to be a school manager of a high enrolment school. It was scary.

P6 I was intimidated by the large number of males in the School Management Team and was afraid to oppose them as I feared they would gang up against me.

One female Principal however demonstrated the exercise of her agency by standing up to male colleagues who attempted to demean her as shown below:

P10: Yes, there was one who enjoyed calling me by first name in public and I stood my ground told him in no uncertain terms that it was not professional.

Agency (the people), according to Archer (1996), refers to the personal and psychological makeup of individuals, their social roles and relates to the capacity that people have to act in specific ways. Agents can engage in concerted action to re-shape or retain the structural or cultural features they inherit in specific institutional settings. As the Department of Education (Republic of South Africa 2004) cited in Nzeli (2013) points out, the women manager may be managers' worst enemy as this feeling of inferiority makes women managers let everyone walk over them instead of taking charge. When a woman does not approve herself, she must not expect others to value her. Low self-esteem affects one's performance at work. Howe-Walsh \& Turnbull (2016) comment that, individual perceptions of ability challenge many women. The data in their study highlights how many women lack confidence in their ability and they conclude that this lack of self-belief acts as a barrier to women career advancement. 


\section{Conclusion}

In conclusion, among the challenges faced by female principals, the most prominently featuring are; negative attitudes from educators regardless of gender; negative attitudes from some parents, though to a limited extent; jealousy; being undermined because of their gender and lack of agency due to lack of self-confidence on the part of the female school principals themselves.

Based on the findings of the study, it can also be concluded that female principals are not well received by other staff members at the schools, with the majority of the staff members expressing an element of doubt in female school managers' ability to lead. Female Principals themselves indicated that male dominance was an entrenched culture among male staff members in general and male School Management Team (SMT) members in particular. Gender awareness workshops for male staff members can, in the researcher's view go a long way in mitigating these negative effects patriarchy.

The study also concludes that women managers are not perceived as incompetent and unable by male colleagues only, but also by female staff members. As results showed, female colleagues were described as being jealous of other females. One would have expected the female staff members to support female schools principals because they share the same common feature which is their femaleness. However as the review of literature has shown, the effect of culture and tradition, wherein females are enculturated to believe that they are inferior to and have to bow down to males could have impacted on how female educators viewed female school principals.

The study concludes that attitudes of the parents, SGB members and the community at large on female principals was generally positive. This is indeed a positive sign which, it is hoped might eventually filter down to the school context as schools are part of the communities they serve.

The difficulty of the part of female school principals to strike a balance between work and family responsibilities is also a major conclusion from this study. Such a dilemma leaves the female school principals having to choose between career advancement and the risk of family breakdowns. It however remains the optimistic hope of the researcher that it is indeed possible to break the glass ceiling. 


\section{Reference}

Arar, K., \& Abramovitz, R. (2013).Teachers' attitudes toward the appointment of women as school leaders: The case of the Arab education system in Israel. Management in Education, 27(1), 32-38.

Archer, M.S. (1995). Realist Social Theory: The Morphogenetic Approach. Cambridge: Cambridge University Press.

Archer, M.S. (1996). Culture and Agency. The Place of Culture in Social Theory. Cambridge: Cambridge University Press.

Archer, M.S. (2000). Being Human: The Problem of Agency. Cambridge: Cambridge University Press.

Anewu, G. (2010). Challenges facing female administrators in senior high schools in the Accra Metropolis. (Unpublished Masters Dissertation) Ghana: University of Cape Coast.

Austin, M. (2016). Women in education, science and leadership in New Zealand: a personal reflection. Studies in Higher Education, 41(5), 914-919. DOI: 10.1080/03075079.2016.1147725

Bilen-Green, C., Froelich, K.A., \& Jacobson, S.W. (2008). The Prevalence of Women in Academic Leadership Positions and Potential Impact on Prevalence of Women in the Professorial Ranks. Paper presented at the Women in Engineering Proactive Network Conference, St. Louis, Missouri June 8 to 102008.

Burton, L.J., \& Weiner, J.M. (2016). "They Were Really Looking for a Male Leader for the Building": Gender, Identity and Leadership Development in a Principal Preparation Program. Frontiers in Psychology, 7, 1-144. Doi: 10.3389/fpsyg.2016.00141.

Bush, T., \& West-Burnham, J. (1994). The principles of educational management. Harlow: Longman.

Chan, A.K., Ngai, G.S., \& Choi P. (2016). Contextualising the career pathways of women principals in Hong Kong: a critical examination. Compare: A Journal of Comparative and International Education, 46(2), 194-213. DOI: 10.1080/03057925.2014.884919.

Chisholm, L. (2001). Gender and leadership in South African educational administration. Gender and Education, 13(4), 387-399. 
Chisholm, L., September, J. (2005). Gender Equity in South African Education 1994-2004: Perspectives from Research, Government and Unions. Cape Town: HSRC Press.

Chmuck, P.A. (1986). A new world, a different game. Education leadership, 43(5), 60-61.

Cundiff, J.L., \& Vescio, T.K. (2016). Gender Stereotypes Influence How People Explain Gender Disparities in the Workplace. Sex Roles, 75,126138.

Davis, D.R., \& Maldonado, C. (2015). Shattering the Glass Ceiling: The Leadership Development of African American Women in Higher Education. Advancing Women in Leadership, 35, 48-64. Retrieved from http://advancingwomen.com/awl/awl_wordpress/ISSN 1093-7099

Danermark, B., Ekström, M., Jakobsen, L., \& Karlsson, J.C. (2005). Explaining Society: Critical Realism in the Social Sciences. New York: Tailor and Francis.

Day, D.V. (Ed) (2014). The Oxford handbook of leadership and organizations. New York: Oxford University Press.

Denzin, N., \& Lincoln. Y (Eds.). (2000). Handbook of Qualitative Research. $\left(2^{\text {nd }}\right.$ Ed). USA: Sage Publications.

Department of Education (1997) Gender Equity in Education: Report of the Gender Equity Task Team. Pretoria: Government Printers.

Diko, N. (2007). Changes and continuities: Implementing of gender equality in a South African High School. Africa Today, 54(1), 106-116.

Diko, N. (2014). Women in educational leadership: The case of Hope High School in the Eastern Cape Province, South Africa. Educational Management Administration \& Leadership, 42(6), 825-834.

Drake, P., \& Owen, P. (1998). Gender and Management Issues in Education An International Perspective. Philadelphia: Open University Press.

Faulkner, C. (2015). Women's experiences of principalship in two South African high schools in multiply deprived rural areas: A life history approach. Educational Management Administration \& Leadership, 43(3), 418-432.

Gill, J., Arnold, P. (2015). Performing the principal: school leadership, masculinity and emotion. Int. J. Leadership. Educ, 18, 19-33. Doi:10.1080/13603124.2014.987180 


\section{Ndebele - Gender and School Leadership}

Gobena, L. (2014). Major factors that affect female teachers' participation in school leadership: The case of public primary schools in Jimma Town. (Unpublished Masters Dissertation). Jimma: Jimma University. http://opendocs.ids.ac.uk/opendocs/handle/123456789/5474

Greyling, S.C.M., \& Steyn, G.M. (2015). The Challenges facing Women aspiring for School Leadership Positions in South African Primary Schools. Gender \& Behaviour, 13(1), 6607-6620.

Greyvenstein, L.A. (2000). Women: the secondary species in education? South African Journal for Education, 16(2), 75-81.

Hannum, K.M., Muhly, S.M., Zalabak, P.S.S., White, J.S. (2015). Women Leaders within Higher Education in the United States: Supports, Barriers, and Experiences of Being a Senior Leader. Advancing Women in Leadership, 35, 65-75. Available online at http://advancingwomen.com/awl/awl_wordpress/

Hill, C., Miller, K., Benson, K., \& Handley, G. (2016). Barriers and bias: the status of women in leadership. Washington: American Association of University Women.

Hoobler, J.M., Lemmon, G., \& Wayne, S.J. (2011). Women's underrepresentation in upper management: New insights on a persistent problem. Organizational Dynamics, 40, 151-156.

Hora, E.A. (2014). Factors that affect Women Participation in Leadership and Decision Making Positions. Asian Journal of Humanity, Art and Literature, 1(2), 97-118.

Howe-Walsh, L., \& Turnbull, S. (2016). Barriers to women leaders in academia: tales from science and technology. Studies in Higher Education, 41(3,415-428. DOI: 10.1080/03075079.2014.929102.

Kaparou, M., \& Bush, T. (2007). Invisible barriers: the career progress of women secondary school principals in Greece. Compare, 2, 221-237.

Kele, T., \& Pietersen, J. (2015).Women leaders in a South African higher education institution: Narrations of their leadership operations. OIDA International Journal of Sustainable Development 08(05), 11-15.

Kiamba, J.M. (2008). Women and leadership positions: Social and cultural barriers to success. Wagadu: Women's Activism for Gender Equity in Africa, 6, 7-28. 
Lakshmi, C.N.S.S. (2015). "Differences in Leadership Styles between Genders: Out comes and Effectiveness of Women in Leadership Roles". MBA Student Scholarship.Paper

35.http://scholarsarchive.jwu.edu/mba_student $/ 35$

Longman, K.A., \& Anderson, P.S. (2016). Women in Leadership: The Future of Christian Higher Education. Christian Higher Education, 15(1-2), 24-37. DOI: 10.1080/15363759.2016.1107339.

Lumby, J. (2003). Managing motivation. In: J Lumby, D Middlewood, ESM Kibawe (Eds.): Managing Human Resources in South African Schools. pp. 155-170. London: Commonwealth Secretariat,

Lumby, J., \& Azaola, M.C. (2014). Women principals in South Africa: gender, mothering and leadership. British Educational Research Journal, 40(1), 30-44. DOI: 10.1002/berj.3028

Lunyolo, G.H., Ayodo, T.M.O., Tikoko, B., \& Simatwa, E.M.W. (2014). Socio-cultural Factors that Hinder Women's Access to Management Positions in Government Grant Aided Secondary Schools in Uganda: The Case of Eastern Region. Educational Research, 5(7), 241-250. DOI: http:/dx.doi.org/10.14303/er.2014.200.

Madsen, S. R., Ngunjiri, F. W., Longman, K. A., \& Cherrey, C. (2015). Women and leadership around the world. Charlotte, NC: Information Age.

Mahlase, S. (1997). The Careers of Women Teachers under Apartheid. Harare: SAPES Books.

Mayer, C.H., \& Surtee, S. (2015). The Leadership Preferences of Women Leaders Working in Higher Education. Multidisciplinary Journal of Gender Studies, 4(1), 612-636. doi:10.4471/generos.2015.49

Mdluli, C.N.P. (2002). An evaluative study of the leadership style of female Principals. (Unpublished Masters Dissertation). Durban: University of Zululand.

Merchant, K. (2012). "How Men And Women Differ: Gender Differences in Communication Styles, Influence Tactics, and Leadership Styles." CMC Senior Theses. Paper 513. http://scholarship.claremont.edu/cmc_theses/513

Mollel, N., \& Tshabangu, I. (2014). Women in Educational Leadership: Conceptualizing Gendered Perceptions in Tanzanian Schools. Educational Research International, 3(4), 46-54. 


\section{Ndebele - Gender and School Leadership}

Moorosi, P. (2008). Creating linkages between private and public: Challenges facing women principals in South Africa. South African Journal of Education 27(3): 507-521.

Morley, L., \& Crossouard, B. (2016a). Women's leadership in the Asian Century: does expansion mean inclusion? Studies in Higher Education, 41(5), 801-814. DOI: 10.1080/03075079.2016.1147749

Morley, L., \& Crossouard, B. (2016b). Gender in the neoliberalised global academy: the affective economy of women and leadership in South Asia. British Journal of Sociology of Education, 37(1), 149-168. DOI: 10.1080/01425692.2015.1100529

Msila, V. (2013). Obstacles and Opportunities in Women School Leadership: A Literature Study. Int J Edu Sci, 5(4), 463-470.

Nan-Chi, T. (2006). Senior Women Leaders in Higher Education Overcoming Barriers to Success. Ph.D. Thesis, Unpublished. Michigan: Eastern Michigan University.

Nazemi, S., Mortazavi, S., \& Borjalilou, S. (2012). Investigating factors influencing women $s$ inclination in adopting managerial positions in Iranian higher education. Interdisciplinary Journal of Contemporary Research in Business, 4(7), 722-732.

Nzeli, K.A. (2013). Challenges faced by female headteachers in the management of secondary schools: a case of Kangundo District in Machakos County, Kenya. (Unpublished M.Admin. Dissertation) Nairobi: Kentata Universty.

Quinn, L. (2006). A Social Realist Account of the Emergence of a Formal Academic Staff Development Programme at a South African University. Ph D Thesis, Unpublished. Grahamstown: Rhodes University.

Quinn, L. (2012). Enabling and constraining conditions for academic staff development. In: L Quinn (Ed.): Reimagining Academic Staff Development: Spaces for Disruption, pp. 27-50. Cape Town: SUN MeDIA Stellenbosch.

Republic of South Africa. (1996). Government Gazette 34620: South African Schools Act No. 84 of 1996. Pretoria: Government printers

Republic of South Africa. (1996). Constitution of the Republic of South Africa Act No. 108 of 1996. Pretoria: Government printers.

Sanderson, R.E., \& Whitehead, S. (2016). "The gendered international school: barriers to women managers' progression". Education 
Training, 58(3), 328 - 338. http://dx.doi.org/10.1108/ET-06-20150045.

Schwanke, D.A. (2013) Barriers for Women to Positions of Power: How Societal and Corporate Structures, Perceptions of Leadership and Discrimination Restrict Women's Advancement to Authority. Earth Common Journal, 3(2), 1-2.

Shava, G.N., Ndebele, C. (2014). Challenges and Opportunities for Women in Distance Education Management Positions: Experiences from the Zimbabwe Open University (ZOU). J Soc Sci, 40(3), 359-372.

Shakeshaft, C. (1993). Organizational Theory and Women. Washington: Educational Research Association.

Sloan, R.G. (1999). Women in Leadership Roles. Paper Presented as Sam Houston State University, Huntsville, Texas October 1999.

Uwizeyimana, D.E., Modiba, N.S., \& Mathevula, N.S. (2014). Barriers to Women's Promotion in Primary School Management Positions. J Soc Sci, 41(3), 353-362.

Van Deventer, I., \& Kruger, A. G. (Eds.) (2003). An educator's guide to school management skills. Pretoria: Van Schaik.

Weeks, W. J. (2009). Factors Relative to the Career Advancement and Seminar Attendance of Women Managers. Atlanta, Georgia: University Microfilms International.

Wills, G. (2016). An economic perspective on school leadership and teachers' unions in South Africa. PhD. Thesis, Unpublished. Stellenbosch: Stellenbosch University.

Wragg, E. C. (1994). Conducting and analysing interviews, in: N. Bennett, R. Glatter \& R. Levacic (Eds.), Improving Educational Management through Research and Consultancy London: Open University Press.

Zikhali, J., \& Perumal, J. (2016). Leading in disadvantaged Zimbabwean school contexts: Female school heads' experiences of emotional labour. Educational Management Administration \& Leadership, 44(3), 347-362.

Zinyemba, A. (2013). Leadership challenges for women managers in the hospitality and financial services industry in Zimbabwe. International Journal of Advanced Research in Management and Social Sciences, 4: $50-57$. 
1605 Ndebele - Gender and School Leadership

Zwane, P.D. (2003). Challenges facing female managers at Emondlo circuit in Nqutu District. (Masters Dissertation, Unpublished.) Kwa Dlangezwa: University of Zululand.

Clever Ndebele Currently director of the Centre for University Teaching and Learning at Sefako Makgatho Health Sciences University, South Africa.

E-mail address: clever.ndebele@ @mu.ac.za 